\title{
Benefits of Social Media to Improve The Sales Product
}

\author{
Respi Silva ${ }^{1}$, Yayah Sutisnawati ${ }^{2}$ \\ \{respisilva@mahasiswa.unikom.ac.id ${ }^{1}$, yayah.sutisnawati@email.unikom.ac.id ${ }^{2}$ \} \\ Departemen Manajemen, Universitas Komputer Indonesia, Indonesia ${ }^{1}$, \\ Departemen Keuangan dan Perbankan, Universitas Komputer Indonesia, Indonesia ${ }^{2}$
}

\begin{abstract}
The writing of this paper aims to explain the benefits of social media to improve the sales of a product, expand market targets, and share the information faster. This research used a descriptive method to present a complete picture of some situations of the variables under study. The results of this study are to find out how much social media is used to increase product sales and attract consumers to be interested in the products sold. Getting more consumers from social media can increase product sales, so it can be said that social media has helped turn passive buyers into loyal and active customers.
\end{abstract}

Keywords: Social media, online, sales, marketing.

\section{Introduction}

Social media is an available tool that means to increase sales targets and know the range of all promotional activities carried out. Profitable things can be reached if the online shop entrepreneurs could utilize social media in the right way to carry out their role as the right place and tool for effective promotion. To facilitate sales promotion, recently the company prefers practical methods, such as using social media. The most common goals of using social media are 1 . To build relationships, 2. To build a brand, 3. For publicity, 4. For promotions, and 5. For market research [1].

The development of technology and social media allow people to market their products with a new approach. The method could be in the form of endorsements through artists' accounts, Instagram celebrities, tweets, or YouTube videos that become viral. Online product advertising can also be in the form of long writing written by reviewers, bloggers, and others. All of them is targeting those who are active in the internet world [2]

Social media is indeed a medium for socialization and interaction, as well as interesting other people to see and visit the link that contains information about the product. It can also be used as the easiest and cheapest marketing media. The small and medium enterprises (SMEs) also used social media as a marketing tool that are interactive in services to build a better communication with customers and prospective customers, as a facility for selling and buying products online [3].

According to Philip Kotler and Kevin Lane Kelleris, social media is a medium that is used by consumers to share text, images, sounds, and video information with other people, companies, or vice versa.[4]

According to Chih-Chin Liang and Hanh Thi Dang, components of corporate factors, social and environmental groups influence buying interest. The ease of use, product information, social media experience, social influence, and gender differences directly influence online purchases 
through social media [5]. Therefore, marketers apply social media for promoting their products because social media is a marketing medium that is important in reaching young market segments in a faster and more efficient way. [6]

According to Van Dijk, quoting what Stanley Milgram did, the average of each elements in a unit will be interrelated according to the six degrees of separation, which states that humans can connect with other humans with at most six interconnected people. [7]

Entrepreneurs are very important in reducing the number of unemployed; those who are unemployed will get income to save so that people are not poor anymore because they already have income from a business. [8]

In a recent study conducted by We Are Social and Hootsuite, it was revealed that Indonesian people are very fond of visiting social media. As observed, at least there are around 130 million Indonesians who active in various social media, ranging from Facebook, Instagram, Twitter, and others. This report also revealed that in January 2018, the total of Indonesian population was 265.4 million, while internet usage reached 132.7 million users. When comparing the number of internet users with social media users, this means that around 97.9 internet users in Indonesia have used social media. Whereas, when compared to the total population of Indonesia, this means that approximately 48 percent of Indonesia's population has used social media. In this data, also seen if 120 million users, or approximately 92 percent of the total social media users, come from mobile devices. Of course, this amount is very large [9].

From a business point of view, social media is about enabling conversation. Social media is also about how the conversation can be produced, promoted, and made for an income [10]. The purpose of this research is to find out how much social media is used to increase product sales. The results of this study are to find out how to attract consumers to be interested in the products sold. Getting more consumers from social media can increase product sales, so it can be said that social media has helped turn passive buyers into loyal and active customers.

\section{Method}

This study used descriptive methods to find out the benefits of social media to increase product sales. The business development on social media that we observe is Instagram. The techniques used for data collection were literature studies and online data searches which then analyzed according to the descriptive method. This research also used previous research studies that discuss the development of social media for online businesses.

\section{Results and Discussion}

Marketing strategies are needed to attract the customers in the products sold, and the following statements are ways to increase product sales on Instagram. The benefits of business features help users to expand their market reach and optimize business Instagram accounts. The access in the insights include several things ranging from the statistic on the number of followers and submissions, to the number of impressions, reach, impression profile, number of site clicks, phone, and email. Anyone can also see the most popular and most accessed posts by users. With this insightful data, of course it will be better to optimize the Instagram account (Figure 1). 


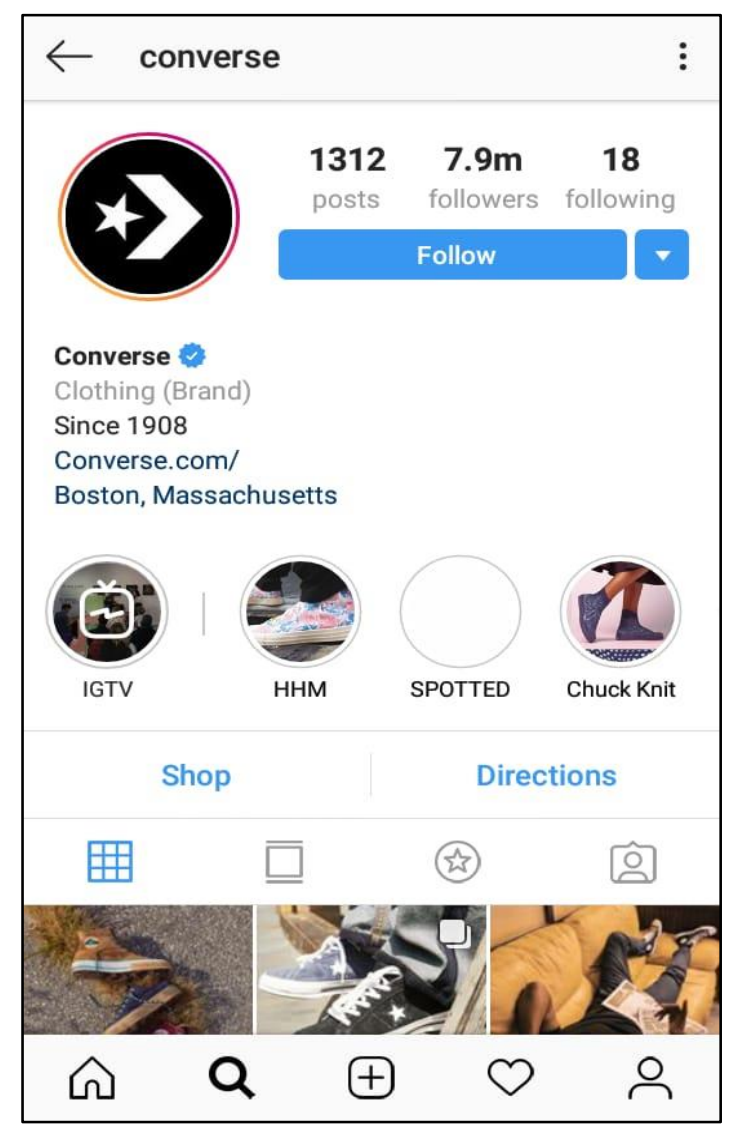

Fig 1. Manage Instagram accounts in business profiles. This Figure was adapted from https://www.instagram.com/converse/ on July 18, 2018.

The first thing that people will see when opening an online store account is the profile of the account, and then they will determine whether to follow the account or not. The profile must be interesting. If the business is still small or medium scale, it is good to put the logo as a profile photo more professional, a clear account's description and a filled link section (Figure 2). 


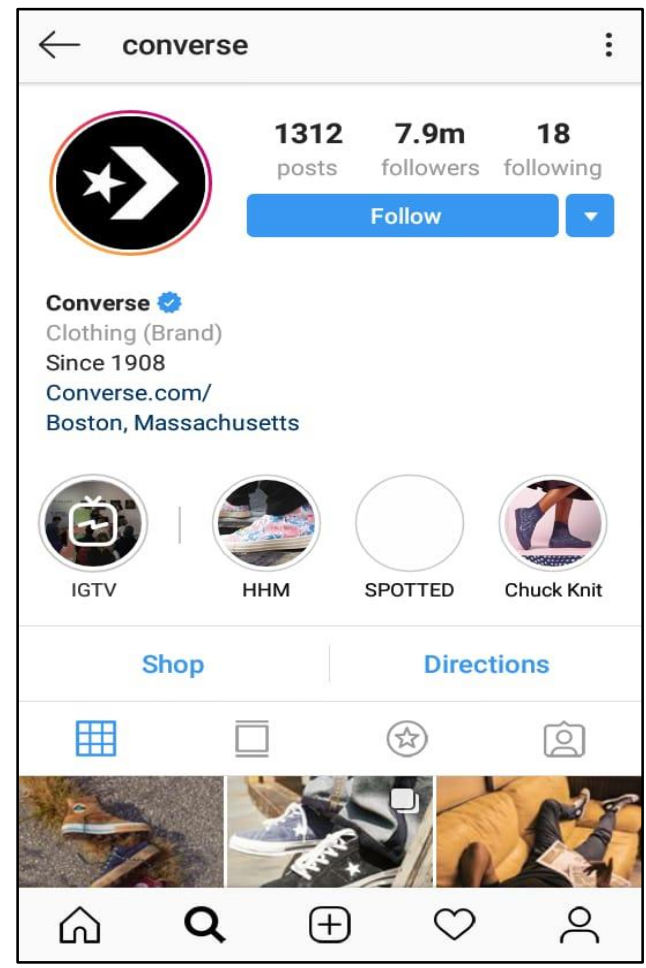

Fig 2. Create an online store profile Looks attractive. This Figure was adapted from https://www.instagram.com/converse/ on July 18, 2018.

On Instagram, photos include the commodities sold. Maybe the online store A and online shop $\mathrm{B}$ sell the same item, but because the photos by online store A is in better quality, so the goods there sold faster. This case often happens, the quality of the existing photos will affect people about the sold item. Hence, upload a good quality photo to create a better impression (Figure $3)$. 


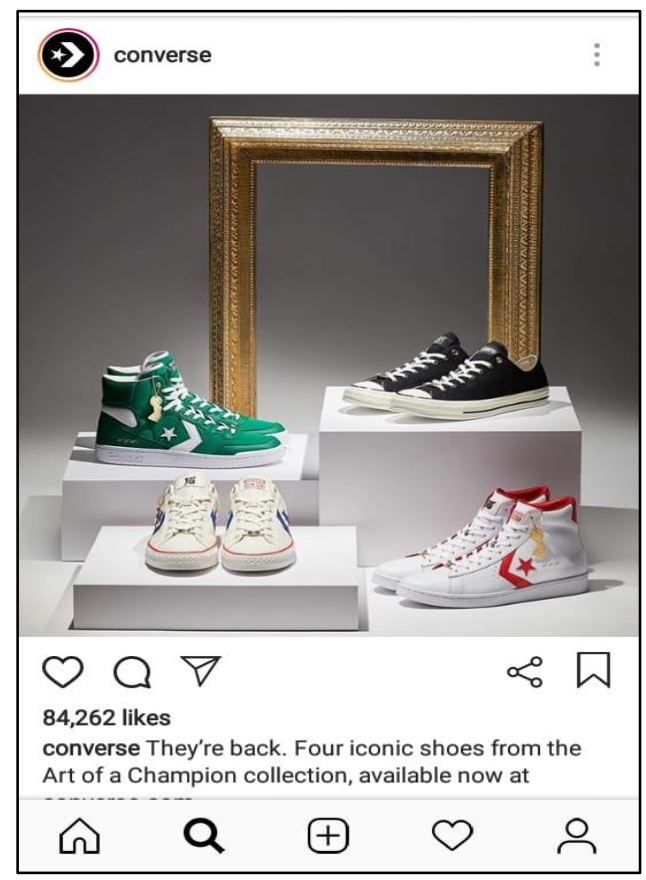

Fig 3. Upload high-quality photos. This Figure was adapted from https://www.instagram.com/converse/ on July 18, 2018.

All photos on the Instagram account resemble the store-fronts. The neater it looks, the more attractive it will be. Of course it will sell faster if it is interesting. Most people like to see all neat online stores. Usually, it will provoke them to scroll more to the online store account (Figure 4). 


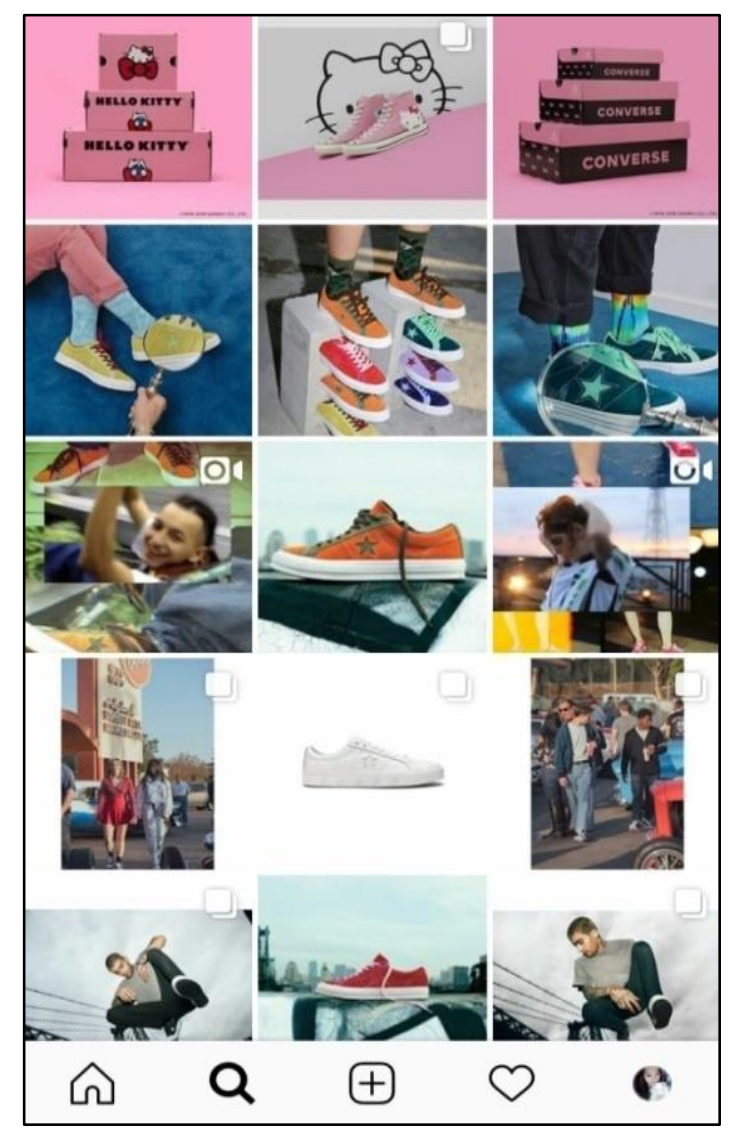

Fig 4. Note the neatness of the photo. This Figure was adapted from https://www.instagram.com/converse/ on July 18, 2018.

One way to get the attention of many people is to upload interesting content. Anyone can apply this method using a video. Upload videos of 3, up to 60 seconds with creative ideas. Before uploading a video, make sure that it will be the audience to watch and respond to the video (Figure 5). 


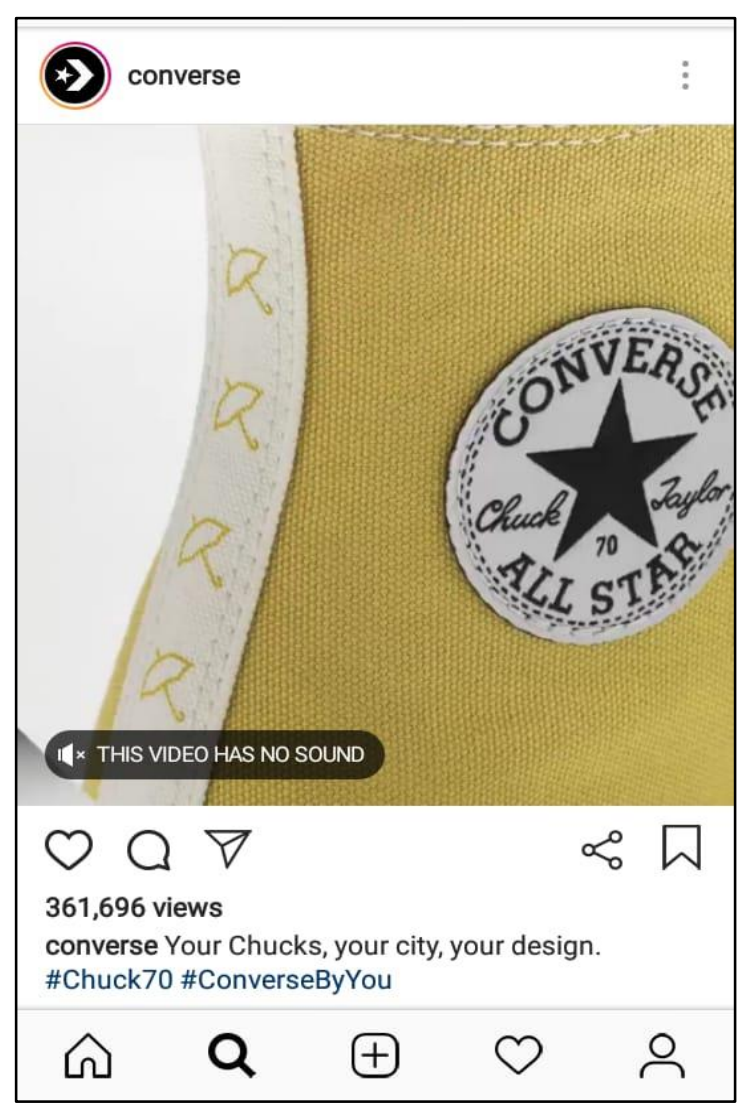

Fig 5. Upload interesting videos. This Figure was adapted from https://www.instagram.com/converse/ on July 18, 2018.

Instagram's timeline changes quickly, so the photo content could be buried quickly. Instagram's hashtags are a way to attract the attention of others to visit the business account. The hashtag serves to combine photo and video content that is connected to the keywords that will appear if someone searched using the search facilities. However, do not use hashtags too often. Put the keywords that are relevant to the brand, and learn about popular hashtags. Instagram is the right tool to market the brand. (Figure 6). 


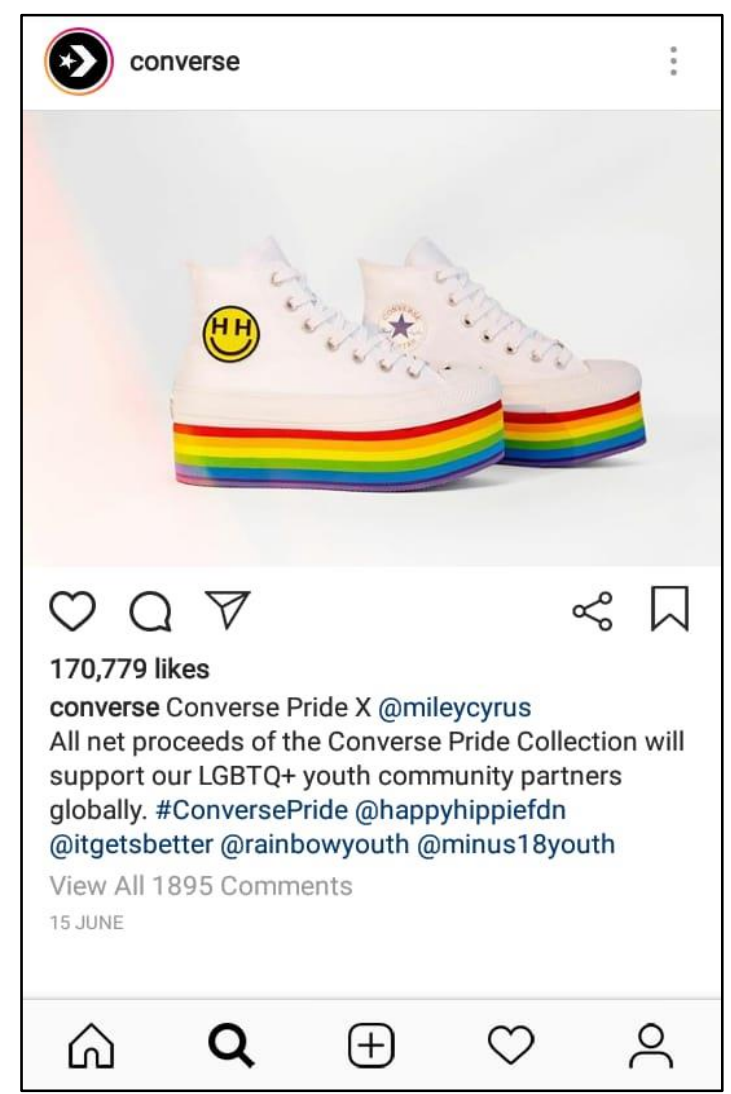

Fig 6. Use hashtags. This Figure was adapted from https://www.instagram.com/converse/ on July 18, 2018.

In order to make the online store being famous and many people who want to buy the product. The marketing strategies such as holding quizzes, discount promotions, or paid promotions by asking celebrities to introduce the products to their followers. Another way by making artists as models, such as converse shoes that make Zayn as a model for their shoes (Figure 7). 


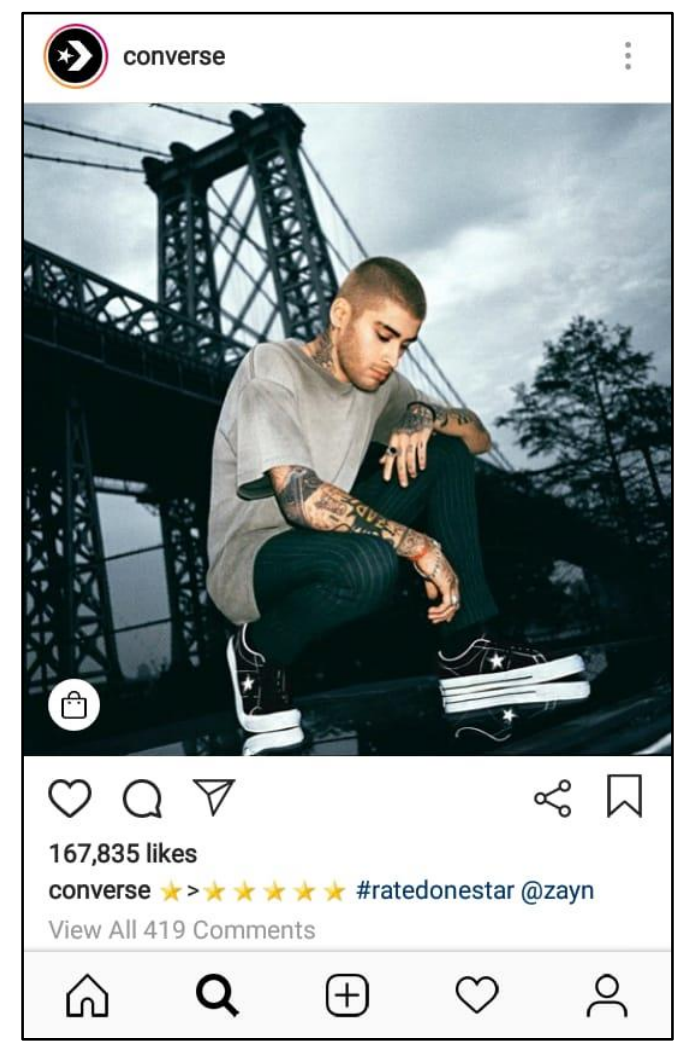

Fig 7. Think of Marketing Strategies. This Figure was adopted from https://www.instagram.com/converse/ on July 18, 2018.

Today's society has made Social Media a part of their lifestyle to be able to socialize. Social Media is useful for giving individuals the ability to set personal benefits, connect with other users, create, publish, and respond. With several ways above, it is expected that business people can increase their product sales through Instagram social media, and consumers are satisfied with what they will buy.

\section{Conclusion}

Utilizing social media as an effective business promotion tool that can be accessed by anyone, resulting in that the promotion network can be wider. Social media are a part of marketing for many companies to increase product sales and one of the best ways to reach customers and clients. Social media such as Instagram, blogs, Facebook, Twitter, and YouTube, have several benefits for the company and are faster than conventional media such as print media and TV advertisements, brochures, and leaflets. Social media is easy for people, especially in business and more convenient for people to do online shopping without leaving their home, use cell phones, the internet, and click or search for what we want, everything can be done quickly and efficiently. 


\section{References}

[1] Gunelius, S.: 30-minute social media marketing. McGraw-Hill Professional Publishing. (2010).

[2] Yulaika, Ramdhani.: Media social telah menjadi ajang pemasaran yang efektif. https://tirto.id/mengapa-media-sosial-jadi-sarana-menjual-produk-cu46. (2017).

[3] Morrison.: Periklanan Komunikasi Pemasaran. Terpadu Ramdina Perkasa, Jakarta. (2007).

[4] Kotler, P., \& Keller, K.: Marketing Management, Pearson Prentice Hall. New Jersey, US. (2006).

[5] Liang, C. C., \& Dang, H. T.: Factors influencing office-workers' purchase intention though social media: An empirical study. International Journal of Customer Relationship Marketing and Management (IJCRMM), 6(1), 1-16. (2015).

[6] Maoyan et al.: Customer Purchase Intention Research Based on Social Media Marketing. International Journal of Business and Social Science. Vol 5 No 10 (1), p 92-97. (2014).

[7] Van Dijk, J. A.: The Network Society. Second Edition. London. (2006).

[8] Soegoto, E. S.: Entrepreneurship Menjadi Pebisnis Ulung Edisi Revisi. Elex Media Komputindo. (2014).

[9] Simon, Kemp.: Essential Insight Into Internet, Social Media, Mobile, and Ecommerce Use Around the World. https://techno.okezone.com/read/2018/03/13/207/1872093/ini-jumlah-total-pengguna-mediasosial-indonesia. (2018).

[10] Safko, L., \& Brake, D. K.: The social media bible: tactics. Tools \& for Business Success, Hoboken, New Jersey. (2009). 